\title{
THE BRAZILIAN CIVIL CONSTRUCTION SECTOR AMONG THE CRISIS CAUSED BY THE PANDEMIC COVID-19: IMPACTS AND PERSPECTIVES FOR THE FUTURE
}

\author{
Mateus Evangelista da Silva ${ }^{a}$, Sávilla Vieira Costa ${ }^{a}$ \\ a Universidade Federal do Cariri, Brazil
}

\begin{abstract}
The crisis caused by the Covid-19 pandemic, affected all sectors of the economy, placing civil construction among the most affected, which was in the recovery phase in the pre-pandemic period. The objective of this work is to reflect on the challenges faced by the sector at this moment, which is delicate for the economy and to point out perspectives for the future. For that, a bibliographic research was carried out on the subjects economy, construction industry and pandemic Covid-19 in Brazil and in the world. The study finds that the moment requires the adoption of new forms of work and more investments in policies aimed at a social and urban infrastructure and requires companies in the sector to apply modern, fast and sustainable construction systems.
\end{abstract}

Keywords: Pandemic Crisis, New Coronavirus, Construction Industry.

\section{O SETOR DE CONSTRUÇÃO CIVIL BRASILEIRO EM MEIO A CRISE CAUSADA PELA PANDEMIA DE COVID-19: IMPACTOS E PERSPECTIVAS PARA O FUTURO}

Resumo: A crise causada pela pandemia de Covid-19, afetou todos os setores da economia, estando a construção civil entre os mais afetados, por se encontrar em uma fase de recuperação no período pré-pandêmico. O objetivo deste trabalho é refletir sobre os desafios enfrentados pelo setor neste momento delicado para a economia e apontar perspectivas para o futuro. Para isto foi realizada uma pesquisa bibliográfica sobre os temas economia, indústria da construção civil e pandemia de Covid-19 no Brasil e no Mundo. O estudo permitiu verificar que o momento chama para a adoção de novos formas de trabalho e mais investimentos em políticas voltadas para infraestrutura social e urbana e exige das empresas do setor a aplicação de sistemas de construção modernos, mais rápidos e sustentáveis.

Palavras-chave: Crise Pandêmica, Novo Coronavírus, Indústria da Construção. 


\section{INTRODUCTION}

COVID-19 is a disease caused by a virus of the coronavirus family, which causes symptoms such as fever, cough and difficulty in breathing and its contagion occurs through respiratory droplets, which gives the disease the characteristic of being highly contagious. So far, there is no validated treatment and complications resulting from the infection may lead the patient to death, with a higher lethality in people with pre-existing comorbidities. The first case of the disease appeared in China in late 2019, expanding rapidly to all continents, being classified on March 11, 2020 by the World Health Organization (WHO) as a pandemic. Throughout history, several examples have been found, such as AIDS, tuberculosis, the outbreak of avian influenza in 2005 and swine flu in 2009 (FRANÇA, 2013) [1].

The outbreak of the disease had a major impact on both public health and the economies of countries. On January 30, 2020, the World Health Organization (WHO) declared that the Covid-19 pandemic constitutes a Public Health Emergency of International Importance, which is the Organization's highest alert level, as provided in its Health Regulations International. According to WHO data, by August 4, 2020, $18,142,718$ people had been infected, among which 691,013 entered the Covid-19 death statistics. In Brazil, the Ministry of Health (MS) has counted to date 2,808,076 infected and 96,096 deaths.

The need for social isolation and paralysis of activities in various sectors, caused unprecedented damage. It is estimated that there will be a significant negative impact on economic activities in the first half of 2020, with the expectation of a slow recovery. By 2021 the global growth rate is expected to be $5.4 \%$, making the Gross Domestic Product (GDP) of 2021 in general roughly 6.5 percentage points below the prediction before the pandemic, on January 19, 2020 (IFM, 2020) [2].

According to a survey carried out by the Brazilian Chamber of the Construction Industry (CBIC) [3], Brazilian civil construction, in the pre-pandemic period, rose, reaching growth of $1.6 \%$ in 2019 , indicating economic recovery. However, the sector was negatively impacted by the crisis generated by the Covid-19 pandemic. The purpose of this article is to reflect on the challenges faced by the Brazilian construction industry as a result of the effects of the crisis generated by the Covid-19 pandemic and to raise perspectives for the future of the sector.

\section{METHODOLOGY}

The methodology adopted for the development of this work consisted of conducting targeted research on the internet, resulting in diversified data distributed among scientific articles, books, official documents, reports, surveys and projections. The keywords used in the searches were: Civil construction; pandemic crisis, economy, negative impacts, construction industry, COVID-19. Works published in the year 2020 that are related to the themes economy, construction industry and pandemic Covid-19 in Brazil and in the World were considered. The study followed the exploratory qualitative research method, which according to Gil (2008) [4], this type of research aims to provide greater familiarity with a new or little explored theme.7 


\section{IMPACTS OF THE CRISIS GENERATED BY THE COVID-19 PANDEMIC ON THE ECONOMY}

The Covid-19 pandemic caused damage to global markets and paralyzed economic activities worldwide, affecting industrial production, trade, employment and income. Some countries have entered a recession and some economists and observers believe that the global economy is expected to suffer for several years before recovering from the coronavirus crisis.

There are still many uncertainties regarding estimates of the economic slowdown in developed countries. Caused by the transmission of the disease, its attempts to contain it and the repercussions on aggregate supply and demand.

According to Thomsen (2020) [5], each month of interruption of basic economic activities in Europe will reduce the gross domestic product (GDP) of these countries by about 3\% per year. In a report issued in April 2020 by the International Monetary Fund (IMF), the GDP growth rate in 2020 for the seven most developed economies is approximately $-6.1 \%$, for developing countries $-1 \%$ and for the world economy is $-3 \%$. However, more recent data, from June of the same year, suggest even deeper drops than previously projected. In which, according to the IMF (2020) [2], the GDP growth rate of the seven most developed economies is $-8 \%$, of developing countries it is $-3 \%$ and the world economy is $-4.9 \%$. The OECD (2020) [6], however, estimates that the level of activity in these countries will decrease by about $2 \%$ each month of social isolation. The OECD also indicates that the impact on demand for goods and services will be greater than its supply.

The interruption of economic activity and uncertainty about the future also caused turbulence in the Brazilian market, with the dollar surpassing record values and sharp falls on the stock exchange. The IMF (2020) [2], projected in the report released in April, a decrease of $5.3 \%$ in the Brazilian GDP. But in June, the entity started to estimate a fall of up to $9.1 \%$.

In a report made by the market and released by the Central Bank of Brazil (2020) [7], Brazilian GDP, in June 2020, was projected with a retraction of $6.54 \%$, as shown in Figure 1. The World Bank (2020) [8], forecasts a GDP of $-8 \%$ for the same year in the country, with a reduction of up to $7.2 \%$ for the region of Latin America and the Caribbean.

Figure 1. Projection of the Brazilian GDP for the year 2020. Source: Central Bank of Brazil (2020) [7]

\section{PIB (\% de crescimento)}

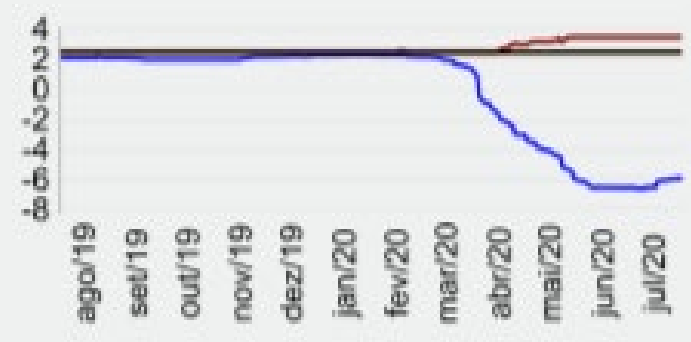




\section{DIRECTIONS TO THE BRAZILIAN CONSTRUCTION SECTOR DURING A PANDEMIC}

The Civil Construction Industry is configured for a country's economy as one of the most important sectors, responsible for driving growth through its production capacity. According to Teixeira and Carvalho (2005) [9], the construction industry is responsible for producing economic infrastructure through the installation of services, which without them, primary, secondary and tertiary activities are not able to function, among which the construction of ports stands out., railways, highways, irrigation systems, energy, communication and others.

According to the São Paulo Civil Construction Industry Union (Sinduscon) [10], the expectation for 2020 was growth, which could reach $3 \%$, representing a recovery for the civil construction sector, which had already accumulated 5 years consecutive falls. However, with the start of the Covid-19 pandemic, the sector was heavily impacted, being affected by a scenario of instability and insecurity for business, which meant that the recovery presented between the end of 2019 and the beginning of 2020 was quickly converted into a fall again. According to a survey carried out by the National Confederation of Industry of Brazil (CNI) [11], which seeks to assess the expectations of the civil construction sector through the Construction Entrepreneur Confidence Index (ICEI-Construção), which uses indicators limited between 0 and 100, which express the 50-point dividing line as a scenario of stability, this index registered 34.8 points in April 2020, setting the lowest value of the historical series since 2015, as shown in Figure 2. $\mathrm{CNI}$ points out that the lack of confidence of the entrepreneur in the civil construction sector, will contribute to the paralysis of investments, making the economic crisis resulting from the Covid-19 pandemic worsen.

Figure 2. Historical series of the Construction Entrepreneur Confidence Index. Source: National Confederation of Industry (CNI) [11] 
ICEI da construção

Índice (0 a 100 pontos)*

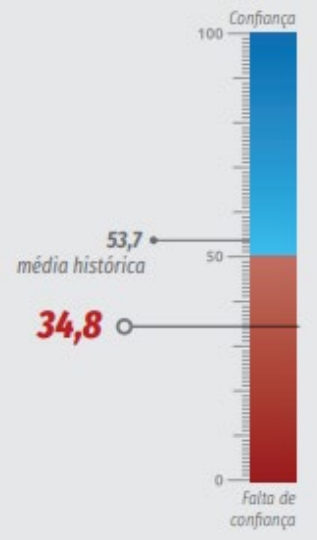

Série histórica

Índice ( 0 a 100 pontos $)^{*}$

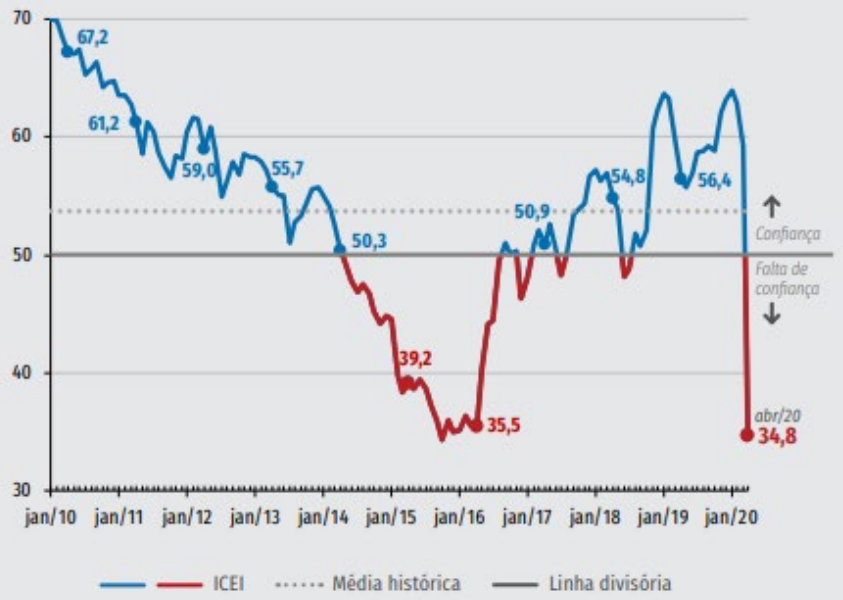

Also, according to a CNI [11] survey, among the main problems pointed out by construction entrepreneurs for the first quarter of 2020 are the high tax burden, the lack of demand resulting from the isolation of consumers, the lack of working capital, excessive bureaucracy and default by customers. Difficulties in transport logistics are among the least pointed problems, although the pandemic has affected not only the progress of the works, but the entire supply chain that supports the sector, resulting in limitations in logistics and availability of materials.

\section{DIRECTIONS TO THE BRAZILIAN CONSTRUCTION SECTOR DURING A PANDEMIC}

The pandemic caused by the new Coronavirus (COVID-19) affected all existing sectors. All daily activities had to be rethought. In Civil Construction it was no different, the moment of crisis offers a unique opportunity to reflect and analyze the sector.

In contrast to the negative impacts suffered during this period, the pandemic allowed companies to strengthen their role of social responsibility with the adoption of practices to support communities. According to Oliva and Oliveira (2008) [12], the concept of social responsibility refers to the inclusion, within the activities developed by the company, of responsible policies and practices, involving suppliers, customers, employees and society in general and seeking to promote of a continuous and selfsustainable improvement in the quality of life of this society.

Costa (2020) [13] conceptualizes that the crisis caused by Covid-19 leads the State to adopt sectoral policies, mainly related to social and urban infrastructure, such as the resumption of works of the Growth Acceleration Program in the peripheral regions (PAC-Favelas) and reinforces that spending in this sector is essential to promote the sustainable growth of the economy, in addition to generating positive externalities, capable of raising the productivity of other investments, adding gains in scale and scope to the various activities. Also, according to Costa (2020) [13], public 
spending on infrastructure plays a role in reducing social and urban inequalities, also contributing to improvements in the preventive health of the population, with civil construction capable of boosting various sectors of the economy.

The urgency also allowed the leveraging of new, faster and more sustainable construction systems to meet the needs of the health system in different parts of the country. With emphasis on the construction of field hospitals spread over several regions, prefabricated modular structures, which allow installation in record time when compared to the usual construction systems. Recently, the Ministry of Health of Brazil (MS) [14] published a specific document that guides the execution of this type of construction, ordinance 1514 of 2020 , defines the technical criteria for the implantation of a Temporary Health Unit for hospital care.

Another important point is the need for remote work, a novelty for most sectors, which had to adapt to this new reality, during the pandemic as companies were subjected to routine changes, including the adoption of the home office. , using digital systems, with some companies adopting the most flexible systems for the work routine, such as alternating activities between office work and home office. This type of practice contributions to the development of the economy in a sustainable way, by saving resources commonly used in the development of the routine tasks of conventional work. The digitization process in the sector also occurs at an accelerated pace. The National Council of Justice of Brazil (CNJ) [15] through Provisions No. 95 and No. 100 of 2020, presented guidelines for the Registry of Real Estate in Registry Offices in a completely digital and remote way.

\section{CONCLUSION}

The current crisis affected all sectors of the economy, among them, the civil construction sector stands out as one of the most affected. In view of the challenges faced, attention must be paid to the negative effects caused by the crisis, since it is not yet possible to project a recovery for the economy, the market is unstable and the degree of investor confidence is compromised. However, the moment calls for an assessment of the future of the sector, which is open to investment in policies that contribute to the sustainable growth of the economy, such as policies related to social and urban infrastructure. It is necessary to look at the development of new technologies and faster construction methods, and above all the adoption of new practices in the work routine, seeking to make human work more flexible and include digital media in business.

\section{REFERENCES}

${ }^{1}$ FRANÇA, N. Endemia, epidemia e pandemia. Available at: < http://www.infoescola.com/doencas/endemia-epidemia-e-pandemia/>. Accessed on: 29 Jul. 2020. 
2IMF - INTERNATIONAL MONETARY FUND. World Economic Outlook, April 2020: The Great Lockdown. Washington: IMF, 2020. Available at: <https://bit.ly/2Wz6cCz>. Accessed on: 03 Aug. 2020.

${ }^{3}$ Câmara Brasileira da Indústria da Construção. PIB Brasil e Construção Civil. Brasília, DF, 2020. Available at: <http://www.cbicdados.com.br/menu/pib-einvestimento/pib-brasil-e-construcao-civil>. Accessed on: 03 Aug. 2020.

${ }^{4} \mathrm{GIL}$, Antonio Carlos. Como elaborar projetos de pesquisa. São Paulo: Atlas, 2008.

${ }^{5}$ THOMSEN, P. O. Europe's Covid-19 crisis and the fund's response. IMF Blog, 2020. Available at: <https://bit.ly/2Wblb5p>. Accessed on: 03 Aug. 2020.

Available

World Economic Outlook Update, June 2020. Washington: IMF, 2020. <https://www.imf.org/en/Publications/WEO/Issues/2020/06/24/WEOUpdateJune2020 >. Accessed on: 03 Aug. 2020

${ }^{6}$ OECD - The ORGANISATION FOR ECONOMIC CO-OPERATION AND DEVELOPMENT. Evaluating the initial impact of COVID-19 containment measures on economic activity. Paris: OCDE, 2020. Available at: <https://bit.ly/3fngaiZ>. Accessed on: 03 Aug. 2020.

7BANCO CENTRAL DO BRASIL. Focus-Relatório de Mercado: Relatório de Mercado-24/07/2020-julho de 2020. Brasilia: BC, 2020. Available at: <https://www.bcb.gov.br/publicacoes/focus/05062020>. Accessed on: 03 Aug. 2020.

${ }^{8}$ THE WORLD BANK. Global Economic Prospects: Latin America and the Caribbean. Washington: IBRD, 2020. Available at: < http://pubdocs.worldbank.org/en/876791588788341170/Global-Economic-ProspectsJune-2020-Regional-Overview-LAC.pdf>. Accessed on: 03 Aug. 2020.

${ }^{9}$ TEIXEIRA, L. P; CARVALHO, F. M. A. de. A Construção civil como instrumento do desenvolvimento da economia brasileira. Revista Paranaense de Desenvolvimento, Curitiba, n. 109, p. 09-26, 2005.

\footnotetext{
${ }^{10}$ Sindicato da Indústria da Construção Civil de São Paulo. SindusCon-SP mantém previsão de crescimento da construção em 2020. São Paulo, SP, 2020. Available at: < https://sindusconsp.com.br/sinduscon-sp-mantem-previsao-de-crescimento-daconstrucao-em-2020>. Accessed on: 03 Aug. 2020.
} 
${ }^{11}$ Confederação Nacional da Indústria. Sondagem Indústria da Construção. Indicadores Econômicos CNI, Brasília, n. 3, p. 05-06, 2020.

${ }^{12}$ Oliva, A., Oliveira, R. RESPONSABILIDADE SOCIAL NA CONSTRUÇÃO CIVIL NO BRASIL: UM CAMINHO QUE PODE VIR A AUXILIAR O ACESSO À MORADIA. Revista INVI. v. 23, n. 63, p. 121-133, 2008.

${ }^{13}$ Costa, S. S. Pandemia e desemprego no Brasil: consequências e medidas de enfrentamento. Revista de Administração Pública. FGV. Rio de Janeiro. v. 54, n. 4. p. $40-42,2020$.

${ }^{14}$ BRASIL. Ministério da Saúde. Portaria 1514/2020. Brasília, 2020.

15BRASIL. PROVIMENTO № 95, DE 01 DE ABRIL DE 2020. Brasília, DF, abril 2020. Available at: < https://atos.cnj.jus.br/atos/detalhar/3265>. Accessed on: 03 Aug. 2020.

PROVIMENTO No 100, DE 26 DE MAIO DE 2020. Brasília,DF, maio 2020. Available at: < https://atos.cnj.jus.br/atos/detalhar/3334>. Accessed on: 03 Aug. 2020. 